Review Article

\title{
Omega-3 Polyunsaturated Fatty Acids: Structural and Functional Effects on the Vascular Wall
}

\author{
Michela Zanetti, Andrea Grillo, Pasquale Losurdo, Emiliano Panizon, Filippo Mearelli, \\ Luigi Cattin, Rocco Barazzoni, and Renzo Carretta
}

Department of Medicine, Surgery and Health Sciences, University of Trieste, Strada di Fiume 447, 34149 Trieste, Italy

Correspondence should be addressed to Andrea Grillo; andr.grillo@gmail.com

Received 25 September 2014; Accepted 26 January 2015

Academic Editor: Yong Q. Chen

Copyright (C) 2015 Michela Zanetti et al. This is an open access article distributed under the Creative Commons Attribution License, which permits unrestricted use, distribution, and reproduction in any medium, provided the original work is properly cited.

Omega-3 polyunsaturated fatty acids (n-3 PUFA) consumption is associated with reduced cardiovascular disease risk. Increasing evidence demonstrating a beneficial effect of n-3 PUFA on arterial wall properties is progressively emerging. We reviewed the recent available evidence for the cardiovascular effects of n-3 PUFA focusing on structural and functional properties of the vascular wall. In experimental studies and clinical trials n-3 PUFA have shown the ability to improve arterial hemodynamics by reducing arterial stiffness, thus explaining some of its cardioprotective properties. Recent studies suggest beneficial effects of n-3 PUFA on endothelial activation, which are likely to improve vascular function. Several molecular, cellular, and physiological pathways influenced by n-3 PUFA can affect arterial wall properties and therefore interfere with the atherosclerotic process. Although the relative weight of different physiological and molecular mechanisms and the dose-response on arterial wall properties have yet to be determined, n-3 PUFA have the potential to beneficially impact arterial wall remodeling and cardiovascular outcomes by targeting arterial wall stiffening and endothelial dysfunction.

\section{Introduction}

Cardiovascular disease is the first cause of death in the developed world. Its main feature is the extensive presence of atherosclerosis, which is anticipated by morphologic and functional changes involving vessel wall and vascular endothelium. Impairment of functional properties of the arteries is strictly related to the morphologic changes in vessel structure and to the alteration in mechanical properties $[1,2]$. Endothelial dysfunction is characterized by impaired endothelium-dependent vasodilation and "endothelial activation," which is associated with a proinflammatory and procoagulatory milieu that promotes development and progression of vascular disease [3,4]. Cardiovascular risk factors are closely linked to the development of endothelial dysfunction and arterial wall stiffness, which are significant predictors of cardiovascular risk and mortality [5, 6]. A synergistic interplay exists among the anatomic structures of the vessel wall, the vascular endothelium, endothelial-derived factors, and circulating cytokines, and such interplay promotes the development of overt atherosclerosis.

Omega- 3 polyunsaturated fatty acids ( $n-3$ PUFA) have shown the potential to beneficially impact fundamental steps involved in the development of preclinical atherosclerosis [7]. By targeting arterial stiffness and endothelial dysfunction, administration of n-3 PUFA may prevent atherosclerosis and cardiovascular disease. A wide range of molecular and physiological pathways are affected by n-3 PUFA administration and are involved in the regulation of arterial stiffness and endothelial dysfunction.

This review will focus on the complex nature of arterial stiffness and endothelial dysfunction and on the translational potential of n-3 PUFA for treating vascular remodeling.

\section{Structural and Mechanical Properties of the Arterial Wall}

Arterial wall consists of a complex morphological organization, with multiple layers designed to maintain the 
fundamental properties of blood carrying and blood pressure regulation. This structure is aimed at maintaining the elastic properties of the arterial wall, which are important for the physiological vascular function [8]. The distensibility of arterial vessels determines the amplitude of pulse pressure as well as the speed of the propagating pulse wave in the arterial system. The loss of elastic properties leads to arterial stiffness, a parameter that has been recognized in recent years as an intermediate endpoint for cardiovascular morbidity and mortality, independently of conventional risk factors for cardiovascular disease [9]. Arterial stiffening or arteriosclerosis, which is caused by the loss of the medial arterial load bearing components of the arterial wall, is pathologically distinct from the obstructive condition of arteries or atherosclerosis, usually defined as the deposition of lipids, white blood cells, and calcium in the arterial wall [10], although these two conditions are closely intertwined [11]. Arteriosclerosis could directly promote cardiovascular disease, by increasing pulsatile load on heart, reducing myocardial blood flow, damaging small vessels in kidney or brain, and by promoting atherogenesis through a reduction in shear stress rate. On the other hand, the presence of atherosclerotic plaques could mechanically alter the properties of the arterial wall.

The assessment of arterial stiffness has been increasingly used in clinical setting, considering its good predictive value for cardiovascular events. A large number of studies have been addressed to understand the mechanisms and factors influencing the development of arterial stiffness and to report interventions able to influence arterial wall properties [9]. Reducing arterial stiffness may be useful to reduce incidence of cardiovascular events and mortality; thus evidence-based treatments would be clinically important, but currently a specifically designed therapeutic strategy for this purpose has not yet been defined. Dietary habits are well-known determinants of the vascular changes occurring in the arterial wall with age, and many studies have focused on the effects of pharmacologic and nonpharmacologic interventions to modulate arterial elastic properties [12].

\section{Effects of n-3 PUFA on Atherogenesis}

A large body of evidence demonstrates the substantial benefits of n-3 PUFA in atherogenesis [13]. n-3 PUFA play several important roles in cellular molecular mechanisms, tissue metabolism and regulation, and act as pleiotropic agents on the cardiovascular system [14]. The mechanisms through which n-3 PUFA interfere with atherogenesis are therefore multiple. Their effect on endothelial dysfunction, oxidative stress, and inflammation, causing the onset of atherogenesis, will be discussed in the next section. The antiatherogenic effect of n-3 PUFA on serum lipid profile, with a reduction in both triglycerides and very-low-density lipoproteins, is well known and has recently been reviewed $[15,16]$. However, it is unclear as to how many of cardiovascular benefits are related to n-3 PUFA lipid lowering effects and how many of them are due to lipid-independent effects.

Regarding the lipid deposition in the arterial layers, which is associated with atherogenesis [17], in a mouse animal model, n-3 PUFA were able to protect the arterial wall by decreasing the LDL uptake and by directing lipid deposition away from the aortic media, by decreasing the lipoprotein lipase expression [18]. This antiatherogenic effect is also associated with a reduction of macrophages and other proinflammatory markers and is enhanced by an incremental replacement of n-3 PUFA in the diet [19].

The proliferation of vascular smooth muscle cells and their lipid accumulation are associated with early lesion in the arterial wall and atherosclerosis promotion [20], highlighting the role of these cells in the pathophysiology of vascular remodeling [21]. An effect of n-3 PUFA on vascular smooth muscle cells activation has been reported in several studies. In culture cells, EPA and DHA were incorporated into phospholipids and slow down the progression of cell cycle, by inhibiting DNA synthesis and replication, thus suppressing vascular smooth muscle cells proliferation [22]. A similar inhibition in the proliferation of vascular smooth muscle cells was observed in human coronary arteries after consumption of fish oil, with a regulation of adhesion molecules on these cells [23].

A specific effect of n-3 PUFA on plaque stability has also been reported, in preventing the rupturing of vulnerable plaques, that leads to arterial thrombosis and obstruction. This effect could explain the reduction in cardiovascular endpoints observed in short-term trials conducted with n-3 PUFA. In patients undergoing carotid endarterectomy, atherosclerotic plaques revealed reduced macrophages infiltration and more stable morphology after n-3 PUFA administration [24]. In a more recent study, in plaques of patients supplemented with n-3 PUFA analyzed after carotid endarterectomy, reduced inflammation and significantly lower levels of mRNA for matrix metalloproteinases were observed [25].

The evaluation of intima-media thickness (IMT) has long been used as a marker of atherosclerotic involvement of arterial walls and as a surrogate endpoint of cardiovascular disease [26]. Although several observational studies reported an inverse association of n-3 PUFA administration, as diet consumption or fish oil administration, a systemic review of human intervention studies could not draw a firm conclusion on the effects of n-3 PUFA administration on IMT [27]. Also more recent trials were inconclusive: a positive effect on IMT was observed in patients with type 2 diabetes [28], although, in elderly men with hypercholesterolemia, a favorable effect on IMT progression was not confirmed, whereas n-3 PUFA imposed an improvement in arterial elasticity [29]. Recent cross-sectional studies reported that DHA levels, but not EPA, have an inverse association with IMT, suggesting that DHA may have a more potent antiatherogenic effect than EPA, independently of other risk factors [30].

\section{Influence of n-3 PUFA on Arterial Wall Stiffening}

As above mentioned, the alteration of mechanical properties of the arterial wall is strictly connected with atherosclerothic involvement. An increased plaque burden and a modification in the composition of arterial layers can hamper arterial elastic behavior. Nevertheless, although sharing some common 
risk factors, these two processes should be considered separately. While effects of n-3 PUFA on atherogenesis, on atherosclerotic plaques stability, and on arterial restenosis have been previously extensively reviewed, we will focus on n-3 PUFA effects on hemodynamic properties of the large arteries. Arterial stiffness, while being firstly determined by traditional risk factors for cardiovascular disease, can be influenced by passive mechanisms that consider mechanical and elastic properties of the vessels, and active mechanisms, regulated by the cellular and molecular function of the endothelium, the vascular smooth cells, and the extracellular matrix [1]. Some of these mechanisms may be influenced by n-3 PUFA intake.

Arterial blood pressure is considered the main determinant of arterial stiffness [9]. A fundamental mechanical property of the arteries is that the arterial wall becomes stiffer when the distending pressure becomes higher. Hypertension can also increase arterial stiffness chronically, by inducing elastin fragmentation and arterial wall remodeling [31]. A large body of studies demonstrated that n-3 PUFA are able to reduce systemic blood pressure [32], and a recent metaanalysis confirmed that a consumption of $>2 \mathrm{~g} / \mathrm{d}$ of EPA + DHA can reduce systolic and diastolic blood pressure in humans [33]. Thus, blood pressure, a main factor associated with arterial stiffening, is influenced by n-3 PUFA intake, explaining part of the beneficial effect of fatty acids on the arterial wall.

Triglyceride levels are known to be affected by n-3 PUFA intake. A supplementation of 2-3 g/d of EPA + DHA can reduce triglyceride levels by $25-30 \%$, although a slight increase of LDL levels was observed in some studies [34]. Lipid abnormalities are well-known determinants for the development of atherosclerotic vessels disease and related abnormalities, such the stiffening of large arteries. In large cross-sectional studies [35] triglyceride levels were strongly associated with arterial properties, although a specific benefit in arterial stiffness levels with therapies targeting triglycerides has not been demonstrated yet.

Elevated heart rate has been shown to be associated with an increased risk of cardiovascular events, and there is evidence that the heart rate is independently associated with the progression of arterial stiffness, both in animal models and in humans [36]. n-3 PUFA supplementation is able to reduce resting heart rate and recovery after exercise. Experimental studies suggested that heart rate lowering could result from direct effects on cardiac electrophysiology [37, 38]. Some studies also suggested that n-3 PUFA might improve neurogenic autonomic function of cardiovascular system, through a modulation of vagal and sympathetic balance [39], and an independent association between aortic stiffness and muscle sympathetic nerve activity has been reported [40].

The effect of n-3 PUFA on classical risk factors for cardiovascular disease may explain the favorable effect on arterial stiffness. Nevertheless other mechanisms, mediated through biochemical cellular signaling and through neurogenic and neuroendocrine pathways, have been explored. The association between endothelial dysfunction and increased arterial stiffness has been demonstrated in vitro [41] and in vivo, both in animals and in humans $[42,43]$. Considering the known effect of n-3 PUFA on endothelial function, which is discussed later in this review, this could be a main explanation of the reduction of arterial stiffness observed in experimental condition of n-3 PUFA supplementation. An enhancement in endothelial-dependent vasodilation of the muscular arterioles leads to a decrease in arterial stiffness because mechanical stresses are transferred to elastin components of the wall and because there is a reduction in reflected pulse waves [44]. A direct vasodilatory effect and an inhibition of constrictor response of DHA have been demonstrated in humans [45]. An interrelation of this vasodilatory effect has been found with different endocrine pathways, as the vascular constrictor response to angiotensin [46] and norepinephrine [47] is attenuated by $n-3$ PUFA in humans.

Therefore, the improvement in arterial properties shown after n-3 PUFA supplementation is multifactorial and involves both passive and active mechanisms of arterial hemodynamics, mediated by multiple cellular and molecular pathways and influenced by some major cardiovascular risk factors (hypertension, blood lipids, and autonomic balance).

\section{5. n-3 PUFA and Arterial Stiffness: In Vivo Studies}

Many studies have focused directly on the evaluation of arterial stiffness after n-3 PUFA supplementation (Table 1). Considering animal models, Sato et al. [48] found that supplementation of EPA reduced aortic PWV in highcholesterol-diet-fed rabbits. Masson et al. [49] reported that pulse pressure obtained from telemetry, an index of arterial stiffness, was reduced by n-3 PUFA in fructose-fed rats, a model of insulin-resistant state. Similarly, Engler et al. [50] demonstrated that DHA supplementation reduced pulse pressure and vascular wall thickness in spontaneously hypertensive rats. More recently our group demonstrated that $n-3$ PUFA supplementation prevents arterial stiffening [51] and other vascular changes, such as baroreflex sensitivity [52] induced by ovariectomy, in a rat experimental model of menopause.

A number of randomized and controlled clinical trials have been conducted to explore the effects of n-3 PUFA on various endpoints related to arterial stiffness. A wellconducted meta-analysis by Pase et al. in 2011 [53], considering 10 intervention trials of n-3 PUFA supplementation, reported that the 2 main outcomes examined (PWV and systemic arterial compliance) were favorably affected by the intervention, thus providing strong support to the use of n-3 PUFA as an evidence-based mean to reduce arterial stiffness. The randomized clinical trials considered in this metaanalysis considered mainly high risk patients, with cardiovascular risk factors ranging from dyslipidemia, hypertension, and obesity to type 2 diabetes. More recent trials confirmed this result with the validated endpoint of carotid-femoral PWV, actually considered the gold standard measure for arterial stiffness [9]. These studies, performed in special patient population such as healthy smokers [54] and metabolic 
TABLE 1: Studies evaluating n-3 PUFA effects on arterial stiffness.

(a) Animal studies

\begin{tabular}{|c|c|c|c|c|c|c|c|c|c|}
\hline First author & & Year & Dose & \multicolumn{2}{|c|}{ Sample } & $\begin{array}{c}\text { Duration } \\
(\mathrm{w})\end{array}$ & $\begin{array}{l}\text { Study } \\
\text { design }\end{array}$ & $\begin{array}{c}\text { Outcome } \\
\text { measure }\end{array}$ & Results \\
\hline Sato $[48]$ & & 1993 & $\begin{array}{l}300 \mathrm{mg} / \mathrm{kg} / \text { day } \\
\mathrm{EPA}\end{array}$ & \multicolumn{2}{|c|}{$\begin{array}{c}\text { High- } \\
\text { cholesterol-diet- } \\
\text { fed } \\
\text { rabbits } \\
\end{array}$} & 12 & AES-PG & cf-PWV & $\begin{array}{c}\text { Prevent increase in } \\
\text { cf-PWV }\end{array}$ \\
\hline Engler $[50]$ & & 2003 & DHA-enriched o & \multicolumn{2}{|c|}{$\begin{array}{c}\text { Spontaneous } \\
\text { hypertensive } \\
\text { rats }\end{array}$} & 6 & AES-PG & $\begin{array}{c}\text { Wall } \\
\text { thickness, PP }\end{array}$ & $\begin{array}{c}\text { Reduce wall } \\
\text { thickness and PP }\end{array}$ \\
\hline Masson [49] & & 2008 & $\begin{array}{l}\text { diet enriched w. } \\
16 \mathrm{~g} / \mathrm{kg} \mathrm{n} \text {-3 PUFA }\end{array}$ & \multicolumn{2}{|c|}{$\begin{array}{l}\text { Fructose-fed } \\
\text { rats }\end{array}$} & 10 & AES-PC & PP & $\begin{array}{c}\text { Prevent increase in } \\
\text { PP }\end{array}$ \\
\hline Losurdo [51] & & 2014 & $\begin{array}{l}0.65 \mathrm{~g} / \mathrm{kg} / \mathrm{d} \text { versu } \\
\text { placebo by gavag }\end{array}$ & \multicolumn{2}{|c|}{$\begin{array}{l}\text { Ovariectomized } \\
\text { rats }\end{array}$} & 8 & AES-PC & cf-PWV & $\begin{array}{c}\text { Prevent increase in } \\
\text { cf-PWV }\end{array}$ \\
\hline \multicolumn{10}{|c|}{ (b) Human studies } \\
\hline First author & Year & \multicolumn{2}{|c|}{ r Dose } & Sample & $\begin{array}{l}\text { Duration } \\
(\mathrm{w})\end{array}$ & Number & $\begin{array}{l}\text { Study } \\
\text { design }\end{array}$ & $\begin{array}{l}\text { Outcome } \\
\text { measure }\end{array}$ & Results \\
\hline $\begin{array}{l}\text { McVeigh } \\
{[110]}\end{array}$ & 1994 & \multicolumn{2}{|c|}{$\begin{array}{l}1800 \text { mg EPA + } 1200 \\
\text { mg DHA/d versus } \\
\text { placebo (olive oil) }\end{array}$} & $\begin{array}{l}\text { Type } 2 \\
\text { diabetes }\end{array}$ & 6 & 20 & RCT-PC & Total AC & $\begin{array}{c}\text { Increase in total } \\
\mathrm{AC}\end{array}$ \\
\hline Nestel [111] & 2002 & \multicolumn{2}{|c|}{$\begin{array}{l}3000 \mathrm{mg} \text { EPA/d } \\
\text { versus } 3000 \mathrm{mg} \\
\text { DHA/d versus } \\
\text { placebo (olive oil) }\end{array}$} & Dyslipidemic & 7 & 38 & RCT-PC & Total AC & $\begin{array}{c}\text { Increase } 36 \% \text { with } \\
\text { EPA, 27\% with } \\
\text { DHA }\end{array}$ \\
\hline $\begin{array}{l}\text { Tomiyama } \\
{[62]}\end{array}$ & 2011 & \multicolumn{2}{|c|}{$\begin{array}{l}1800 \mathrm{mg} \text { EPA/d versus } \\
\text { control (diet therapy) }\end{array}$} & Dyslipidemic & 52 & 84 & RCT-PG & ba-PWV & $\begin{array}{c}\text { Reduction of } \\
\text { ba-PWV }\end{array}$ \\
\hline Hjerkinn [29] & ] 2006 & \multicolumn{2}{|c|}{$6 \begin{array}{l}2400 \text { mg n-3 PUFA } \\
\text { versus control diet }\end{array}$} & Dyslipidemic & 156 & 563 & RCT-PG & cr-PWV & $\begin{array}{l}\text { Decrease in } \\
\text { cr-PWV } 4 \%\end{array}$ \\
\hline Hill [112] & 2007 & \multicolumn{2}{|c|}{$\begin{array}{l}1560 \mathrm{mg} \text { DHA + } \\
360 \mathrm{mg} \text { EPA/d versus } \\
\text { placebo }(6 \mathrm{~g} \\
\text { sunflower oil/d) }\end{array}$} & $\begin{array}{l}\text { Overweight, } \\
\text { hypertensive, } \\
\text { dyslipidemic }\end{array}$ & 6 to 12 & 38 & RCT-PC & $\begin{array}{l}\text { Small and large } \\
\text { AC }\end{array}$ & $\begin{array}{c}\text { Increase in small } \\
\text { AC } 26 \% .\end{array}$ \\
\hline Mita [28] & 2007 & \multicolumn{2}{|c|}{$\begin{array}{l}1800 \mathrm{mg} \text { EPA/d versus } \\
\text { control (no EPA) }\end{array}$} & $\begin{array}{c}\text { Type } 2 \\
\text { diabetes }\end{array}$ & 6 & 64 & RCT-PG & ba-PWV & $\begin{array}{c}\text { Reduction of } \\
\text { ba-PWV }\end{array}$ \\
\hline Wang [113] & 2008 & \multicolumn{2}{|c|}{$\begin{array}{l}540 \mathrm{mg} \text { EPA + } 360 \mathrm{mg} \\
8 \begin{array}{l}\text { DHA versus placebo } \\
\text { capsules }\end{array} \\
\end{array}$} & $\begin{array}{l}\text { Overweight, } \\
\text { hypertensive }\end{array}$ & 8 & 52 & RCT-PC & $\begin{array}{l}\text { Small and large } \\
\text { AC }\end{array}$ & $\begin{array}{c}\text { Increase in large } \\
\text { AC } 21 \%\end{array}$ \\
\hline Satoh [114] & 2009 & \multicolumn{2}{|c|}{$\begin{array}{l}1800 \mathrm{mg} \text { EPA/d + diet } \\
9 \text { versus control (diet } \\
\text { only) }\end{array}$} & $\begin{array}{l}\text { Metabolic } \\
\text { syndrome }\end{array}$ & 12 & 92 & RCT-PG & ca-PWV & $\begin{array}{l}\text { Reduction of } \\
\text { ca-PWV 6\% }\end{array}$ \\
\hline Ayer [115] & 2009 & \multicolumn{2}{|c|}{$\begin{array}{l}32 \mathrm{mg} \mathrm{EPA} / \mathrm{d}+135 \mathrm{mg} \\
9 \text { DHA/d + canola oil } \\
\text { versus control diet }\end{array}$} & $\begin{array}{l}\text { Healthy } \\
\text { children }\end{array}$ & 260 & 616 & RCT-PG & $\begin{array}{l}\text { Carotid artery } \\
\text { distensibility, } \\
\text { cb-PWV, Aix }\end{array}$ & No difference \\
\hline Sjoberg [116] & 2010 & \multicolumn{2}{|c|}{$\begin{array}{l}1560 \mathrm{DHA}+360 \mathrm{mg} \\
\text { EPA/d versus placebo } \\
\text { (sunola oil) }\end{array}$} & Overweight & 12 & 67 & RCT-PC & $\begin{array}{l}\text { Small and large } \\
\text { AC }\end{array}$ & $\begin{array}{c}\text { Increase in large } \\
\text { AC } 14 \%\end{array}$ \\
\hline $\begin{array}{l}\text { Dangardt } \\
{[60]}\end{array}$ & 2010 & \multicolumn{2}{|c|}{$\begin{array}{l}1200 \mathrm{mg} n-3 \text { PUFA } \\
\text { versus placebo }\end{array}$} & $\begin{array}{c}\text { Obese } \\
\text { adolescents }\end{array}$ & 12 & 25 & RCT-PC & cf-PWV & No difference \\
\hline Sanders [58] & 2011 & \multicolumn{2}{|c|}{$\begin{array}{l}1800 \text { mg n-3 PUFA } \\
\text { versus placebo }\end{array}$} & $\begin{array}{l}\text { Healthy } \\
\text { subjects }\end{array}$ & 52 & 312 & RCT-PC & cf-PWV & $\begin{array}{c}\text { Decrease in } \\
\text { cf-PWV }\end{array}$ \\
\hline Haiden [57] & 2012 & \multicolumn{2}{|c|}{$\begin{array}{l}1800 \text { mg n-3 PUFA } \\
\text { versus placebo }\end{array}$} & $\begin{array}{l}\text { Hypertensive, } \\
\text { dyslipidemic }\end{array}$ & 52 & 19 & CT & $\begin{array}{l}\text { ba-PWV, aortic } \\
\text { strain rate }\end{array}$ & $\begin{array}{c}\text { Decrease in } \\
\text { ba-PWV } 1 \% \text {, strain } \\
\text { rate } 17 \% \\
\end{array}$ \\
\hline Siasos [54] & 2013 & \multicolumn{2}{|c|}{$\begin{array}{l}2000 \text { mg n-3 PUFA } \\
\text { versus placebo }\end{array}$} & $\begin{array}{l}\text { Healthy } \\
\text { smokers }\end{array}$ & 12 & 20 & RCT-PC & cf-PWV & $\begin{array}{l}\text { Decrease in } \\
\text { cf-PWV 6\% }\end{array}$ \\
\hline Root [59] & 2013 & \multicolumn{2}{|c|}{$\begin{array}{l}1700 \text { mg n-3 PUFA } \\
\text { versus placebo }\end{array}$} & $\begin{array}{l}\text { Overweight } \\
\text { young }\end{array}$ & 4 & 30 & RCT-PC & cf-PWV & No difference \\
\hline
\end{tabular}


(b) Continued.

\begin{tabular}{lllccccc}
\hline First author & Year Dose & Sample & $\begin{array}{c}\text { Duration } \\
(\mathrm{w})\end{array}$ & Number & $\begin{array}{c}\text { Study } \\
\text { design }\end{array}$ & $\begin{array}{c}\text { Outcome } \\
\text { measure }\end{array}$ & Results \\
\hline Wong [56] & $2013 \begin{array}{l}4000 \mathrm{mg} \text { n-3 PUFA }+ \\
\text { diet versus diet alone }\end{array}$ & Obese & 12 & 13 & RCT-PC & $\begin{array}{c}\text { Small and large } \\
\text { AC }\end{array}$ & $\begin{array}{c}\text { Increase in large } \\
\text { AC 20\%, small AC } \\
2 \%\end{array}$ \\
\hline $\begin{array}{l}\text { Tousoulis } \\
{[55]}\end{array}$ & $2014 \begin{array}{l}2000 \text { mg n-3 PUFA } \\
\text { versus placebo }\end{array}$ & $\begin{array}{l}\text { Metabolic } \\
\text { syndrome }\end{array}$ & 12 & 29 & RCT-PC & cf-PWV & $\begin{array}{c}\text { Decrease in } \\
\text { cf-PWV 5\% }\end{array}$ \\
\hline
\end{tabular}

n-3 PUFA, omega-3 polyunsaturated fatty acids; EPA, eicosapentaenoic acid; DHA, docosahexaenoic acid; PWV, pulse wave velocity; cf, carotid-femoral; ba, brachial-ankle; cr, carotid-radial; PP, pulse pressure; AC, arterial compliance; AES, animal experimental study; RCT, randomized clinical trial; CT, clinical trial; PG, parallel groups; PC, placebo controlled; d, day; w, week.

syndrome patients [55], confirmed a reduction in arterial stiffness. A large study conducted evaluating carotid-radial PWV in elderly men with hypercholesterolemia [29] and systemic arterial compliance in obese patients on a weight loss diet [56] confirmed a favorable effect in arterial stiffness. Considering innovative measurement methods of arterial stiffness, a small open-label study observed an improvement in regional aortic stiffness assessed by strain rate, using tissue Doppler imaging [57]. Three randomized clinical trials conducted with small doses of n-3 PUFA $(<1.8 \mathrm{~g} / \mathrm{d})$ on healthy patients [58] and on young healthy patients with metabolic syndrome [59] or obesity [60] did not find any significant effect on arterial stiffness. In a trial evaluating patients with cardiovascular risk factors a fish oil diet was ineffective in reducing brachial-ankle pulse wave velocity, while the subsequent administration of pure EPA in the same population significantly reduced the arterial stiffness [61]. Considering cross-sectional studies, in general Japanese population, there was no relationship between serum omega3 levels and arterial stiffness, evaluated as brachial-ankle PWV [62], while in a sample of 299 Korean men a regression analysis found a significant inverse association with total n-3 PUFA and carotid-femoral PWV [63].

Despite the few negative results in randomized clinical trials, current evidences generally agree that n-3 PUFA are effective in reducing arterial stiffness in humans. We can speculate that the negative results in these trials [58-60] are due to the small dose of active treatment or to the fact that in these trials a population with a low risk for cardiovascular disease was considered (young patients, healthy volunteers). The preferred use of n-3 PUFA only in high risk patients or in secondary prevention is supported by current guidelines and could be applied also for n-3 PUFA administration for the purpose of reducing arterial stiffness, although well-designed clinical trials considering high and low risk population are needed to support this evidence.

As arterial stiffness is a strong risk factor for cardiovascular disease, n-3 PUFA should be considered, among the wide range of cardiovascular drugs, as a safe and evidencebased choice to positively affect the mechanical properties of arterial wall. Which dose is the best for this outcome and which group of patients should be treated constitute an important area of future research.

\section{Regulation of Endothelial Function and Endothelial Dysfunction}

Classically the term "endothelial dysfunction" strictly refers to reduced endothelium-dependent vasodilation, which is notably associated with impaired bioavailability of the main endothelium-derived relaxing factor, nitric oxide (NO). In addition to promoting vasodilation, $\mathrm{NO}$ is a powerful antiatherosclerotic agent, since it reduces leukocyte adhesion, platelet aggregation, and smooth muscle cell proliferation [64]. In the endothelium NO is produced by the enzyme endothelial nitric oxide synthase (eNOS). Reduced nitric oxide bioavailability can be the result of either decreased production or increased scavenging. Several mechanisms, including downregulation of eNOS expression, posttranslational modifications of eNOS, inhibition of the enzyme catalytic activity, enzyme uncoupling, and circulating eNOS inhibitors result in decreased NO release and endothelial dysfunction $[65,66]$.

On the other hand, a number of studies have shown that reactive oxygen species (ROS), which are increased in many conditions associated with enhanced oxidative stress, determine endothelial dysfunction by quenching NO, reducing its bioavailability and leading to the formation of the highly toxic peroxynitrite [66, 67].

Perturbations of NO bioavailability are usually associated with signs of vascular inflammation and of a prothrombotic and procoagulable state [68]. Therefore, in a comprehensive sense, the term endothelial dysfunction encompasses a wide range of alterations of endothelial function preluding overt atherosclerosis.

Endothelial dysfunction is typically detected in conditions associated with vascular disease, such as hypertension, smoking, diabetes mellitus, hypercholesterolemia, and aging [69]. Clinically, endothelial dysfunction can be noninvasively assessed by measuring flow-mediated dilation (FMD), at the level of the brachial artery or of the coronary bed. This parameter allows determining the capability of the vessel to dilate in response to various stimuli (hyperemia following sphygmomanometer cuff inflation or infusion of muscarinic receptor agonists) [4, 70]. Importantly, several studies have demonstrated the prognostic value of endothelial dysfunction in terms of future cardiovascular events in both populations at low and high cardiovascular risk, its 


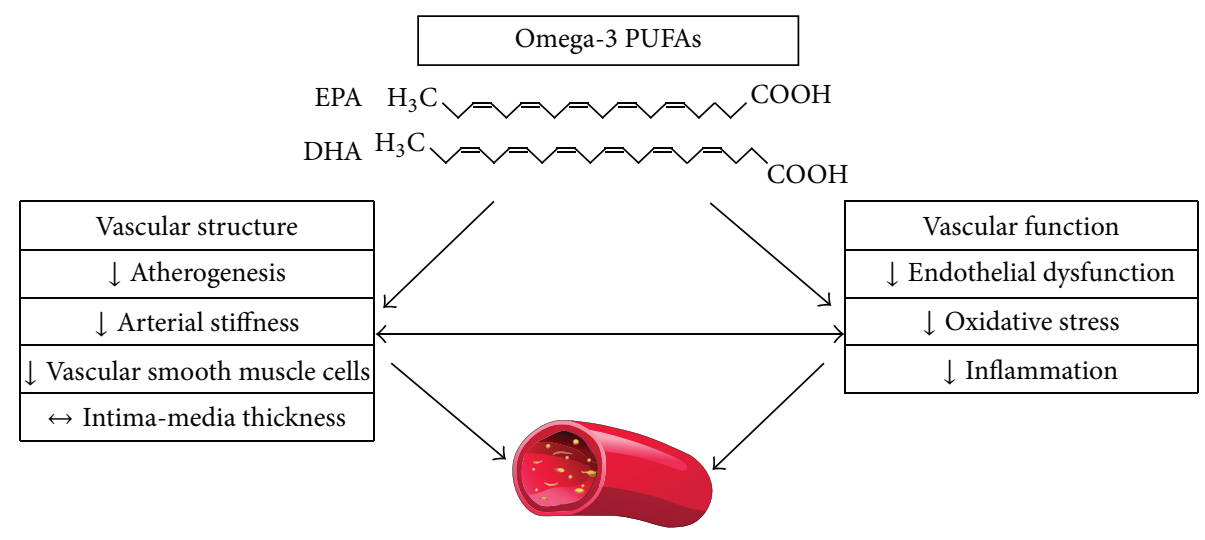

FIGURE 1: n-3 PUFA effects on vascular structure and function.

predictive value being not inferior to validated surrogate markers of vascular function [4,71-73]. Therefore endothelial dysfunction can be considered an early marker of increased cardiovascular risk in patients with or without a previous history of cardiovascular disease.

\section{Influence of n-3 PUFA on Endothelial Function}

The mechanism by which n-3 PUFA influence endothelial function is mediated by their incorporation into biological membrane phospholipids; this allows modulation of membrane composition and fluidity. The importance of endothelial cell membrane composition has been documented by several studies (Table 2). The reason lies in the fact that endothelial cell membrane houses caveolae and lipid rafts where several receptors and signaling molecules crucial for cell function are concentrated [74]. Caveolaeassociated receptor-mediated cellular signal transduction includes important pathways such as the nitric-oxide cGMP pathway, the NADPH oxidase and TNF- $\alpha-\mathrm{NF} \kappa \mathrm{B}$ induced cyclooxygenase-2 (COX-2) and prostaglandin $\mathrm{E}_{2}\left(\mathrm{PGE}_{2}\right)$ activation pathway $[75,76]$. By modulating the composition of caveolae, as described for other classes of lipids [77] n-3 PUFA may exert their beneficial effects, which include increased NO production and reduced production proinflammatory mediators.

Molecular evidence of enhanced eNOS activity/expression following administration of n-3 PUFA derives from experimental studies in endothelial cells in culture or in animals. Wu et al. [78] showed that in bovine aortic endothelial cells and in eNOS knock-out mice EPA induces NO production by stimulating AMP-activated protein kinase (AMPK) induced endothelial nitric oxide synthase (eNOS) activation. Similarly, Omura et al. demonstrated that EPA stimulates eNOS activation in endothelial cells by inducing its dissociation from the inhibitory scaffolding protein caveolin [79]. Likewise, Stebbins et al. reported that DHA promotes eNOS activity by increasing the interaction between eNOS and HSP-90, which activates $\mathrm{PKB} / \mathrm{AKt}$ pathway finally resulting in eNOS phosphorylation and activation [80]. Finally, n-3 PUFA can enhance eNOS activity by reducing the circulating levels of asymmetric dimethylarginine (ADMA), an endogenous inhibitor of eNOS, which is increased in conditions as hypertension, renal failure, and aging [81].

Another mechanism by which n-3 PUFA increase NO production is by directly stimulating eNOS gene and protein expression. Improved vasodilation as a result of $n-3$ PUFA induced upregulation of eNOS gene/protein expression has been documented in a wide series of reports considering physiological and disease animal models including menopause, atherosclerosis, and diabetes mellitus by our and other groups [82-88]. Taken together these data indicate a strong potential of n-3 PUFA to potentiate NO availability by enhancing its production via different molecular mechanisms.

In addition to increasing NO production, n-3 PUFA decrease oxidative stress. This effect is controversial, since the prooxidant activity of long-chain n-3 PUFA especially at high doses has long been debated [89]. However experimental studies conducted so far in cell culture or in vascular beds of experimental animals have shown that relatively large doses of n-3 PUFA improve endothelial function by attenuating ROS production as a result of a direct modulatory effect on the sources of ROS formation, including the enzymes NADPH oxidase and iNOS, finally resulting in reduced peroxynitrite formation $[82,83]$. In retinal endothelial cells in culture exposed to high glucose ALA directly reduces ROS information and increased superoxide dismutase (SOD) activity $[90,91]$. A potentiation of endogenous antioxidant enzyme concentrations in plasma as a direct effect of n-3 PUFA oral administration has also been reported also by other reports [92].

Among the contributors to endothelial dysfunction, n-3 PUFA have shown the potential to attenuate cellular and systemic inflammation. In endothelial cells in vitro $\mathrm{n}$ 3 PUFA attenuate NF- $\kappa$ B activation, resulting in reduced VCAM-1 expression [90]. Additionally, n-3 PUFA exert systemic anti-inflammatory effects by raising the plasma levels of adiponectin [93] and suppressing the production of interleukin 6, interleukin $1 \beta$, soluble $\mathrm{E}$ selectin, and CRP [94]. These effects are dose-dependent, as relatively high doses of n-3 PUFA are required to achieve the antiinflammatory effect and this cannot exclude the fact that 
TABLE 2: Studies evaluating n-3 PUFA effects on endothelial function.

(a) Animal studies

\begin{tabular}{|c|c|c|c|c|c|c|c|c|c|}
\hline \multicolumn{2}{|l|}{ First author } & Year & Dose & Sample & \multicolumn{2}{|c|}{$\begin{array}{l}\text { Duration } \\
(\mathrm{w})\end{array}$} & $\begin{array}{l}\text { Study } \\
\text { design }\end{array}$ & $\begin{array}{l}\text { Outcome } \\
\text { measure }\end{array}$ & \multirow[t]{2}{*}{ Results } \\
\hline Nyby [84] & & 2005 & $\begin{array}{l}\text { Diet enriched wit } \\
60 \% \text { fructose and } \\
4.4 \% \text { n-3 PUFA } \\
\text { versus diet with } \\
60 \% \text { fructose or } \\
\text { control diet }\end{array}$ & $\begin{array}{l}\text { Hyperinsulinemic } \\
\text { rats }\end{array}$ & 8 & & AES-PG & $\begin{array}{l}\text { EDD, } \\
\text { oxidative } \\
\text { stress }\end{array}$ & \\
\hline \multicolumn{2}{|c|}{ Matsumoto [88] } & 2009 & $\begin{array}{l}300 \mathrm{mg} / \mathrm{kg} / \mathrm{day} \\
\text { EPA versus contr } \\
\text { diet }\end{array}$ & Diabetic rats & 4 & & AES-PC & EDD & Improve EDD \\
\hline \multicolumn{2}{|l|}{ Zhang [83] } & 2013 & $\begin{array}{l}\text { Diet enriched wit } \\
\text { ALA } \\
500 \mathrm{mg} / \mathrm{kg} / \text { day } \\
\text { versus control die }\end{array}$ & $\begin{array}{c}\text { Type } 2 \text { diabetic } \\
\text { rats }\end{array}$ & 5 & & AES-PC & $\begin{array}{l}\text { EDD, } \\
\text { oxidative } \\
\text { stress }\end{array}$ & $\begin{array}{l}\text { Improve EDD and } \\
\text { oxidative stress }\end{array}$ \\
\hline \multicolumn{2}{|c|}{$\begin{array}{l}\text { Gortan } \\
\text { Cappellari [82] }\end{array}$} & 2013 & $\begin{array}{l}800 \mathrm{mg} / \mathrm{kg} / \text { day by } \\
\text { gavage versus } \\
\text { control diet }\end{array}$ & $\begin{array}{l}\text { Ovariectomized } \\
\text { rats }\end{array}$ & 8 & & AES-PC & $\begin{array}{l}\text { EDD, } \\
\text { oxidative } \\
\text { stress }\end{array}$ & $\begin{array}{l}\text { Improve EDD and } \\
\text { oxidative stress }\end{array}$ \\
\hline \multicolumn{10}{|c|}{ (b) Human studies } \\
\hline First author & Year & \multicolumn{2}{|c|}{ Dose } & Sample & $\begin{array}{l}\text { Duration } \\
\text { (w) }\end{array}$ & Number & $\begin{array}{l}\text { Study } \\
\text { design }\end{array}$ & $\begin{array}{l}\text { Outcome } \\
\text { measure }\end{array}$ & Results \\
\hline $\begin{array}{l}\text { Woodman } \\
{[117]}\end{array}$ & 2003 & \multicolumn{2}{|c|}{$\begin{array}{l}3800 \mathrm{mg} \text { EPA or } \\
3700 \mathrm{mg} \text { DHA versus } \\
\text { olive oil }\end{array}$} & $\begin{array}{l}\text { Hypertensive type } 2 \\
\text { patients }\end{array}$ & 6 & 30 & RCT-PG & EDD, EID & $\begin{array}{c}\text { Unchanged EDD } \\
\text { and EID }\end{array}$ \\
\hline Engler [118] & 2004 & \multicolumn{2}{|c|}{$4 \begin{array}{l}1200 \mathrm{mg} \text { n-3 PUFA } \\
\text { versus control diet }\end{array}$} & $\begin{array}{c}\text { Hypercholesterolemic } \\
\text { children }\end{array}$ & 10 & 20 & RCT-PC & $\begin{array}{c}\text { EDD, } \\
\text { oxidative } \\
\text { stress, } \\
\text { inflammation }\end{array}$ & $\begin{array}{l}\text { Improved EDD, } \\
\text { unchanged } \\
\text { oxidative stress and } \\
\text { inflammation }\end{array}$ \\
\hline Ros [119] & 2004 & \multicolumn{2}{|c|}{$\begin{array}{l}1100-1700 \mathrm{mg} \mathrm{n}-3 \\
4 \text { PUFA versus } \\
\text { Mediterranean diet }\end{array}$} & $\begin{array}{l}\text { Hypercholesterolemic } \\
\text { patients }\end{array}$ & 4 & 20 & RCT-PG & $\begin{array}{c}\text { EDD, } \\
\text { oxidative } \\
\text { stress and } \\
\text { CRP } \\
\end{array}$ & $\begin{array}{l}\text { Improved EDD, } \\
\text { unchanged } \\
\text { oxidative stress and } \\
\text { inflammation } \\
\end{array}$ \\
\hline Keogh [120] & 2005 & \multicolumn{2}{|c|}{$\begin{array}{l}4700 \text { mg mg n-3 } \\
\text { PUFA versus } \\
\text { isocaloric high } \\
5 \text { carbohydrate, } \\
\text { saturated or } \\
\text { monounsaturated fat } \\
\text { enriched-diet }\end{array}$} & Healthy subjects & 4 & 40 & RCT-PG & $\begin{array}{l}\text { EDD, CRP, } \\
\text { inflammation }\end{array}$ & $\begin{array}{l}\text { Improved EDD in } \\
\text { all groups except in } \\
\text { saturated fat } \\
\text { enriched diet }\end{array}$ \\
\hline $\begin{array}{l}\text { Prabodh } \\
\text { Shah [121] }\end{array}$ & 2007 & \multicolumn{2}{|c|}{$\begin{array}{l}500 \text { mg n-3 PUFA } \\
\text { versus placebo }\end{array}$} & Healthy subjects & 2 & 26 & RCT-PC & EDD, EID & $\begin{array}{l}\text { Improved EDD } \\
\text { and EID }\end{array}$ \\
\hline Wright [122] & 2008 & \multicolumn{2}{|c|}{$\begin{array}{l}3000 \text { mg n-3 PUFA } \\
8 \text { versus standard } \\
\text { therapy }\end{array}$} & $\begin{array}{l}\text { Systemic lupus } \\
\text { erythematosus } \\
\text { patients }\end{array}$ & 24 & 56 & RCT-PG & $\begin{array}{c}\text { EDD, } \\
\text { oxidative } \\
\text { stress }\end{array}$ & $\begin{array}{l}\text { Improved EDD } \\
\text { and oxidative stress }\end{array}$ \\
\hline Schiano [123] & 2008 & \multicolumn{2}{|c|}{$\begin{array}{l}1700-2000 \text { mg versus } \\
\text { standard therapy }\end{array}$} & $\begin{array}{c}\text { Intermittent } \\
\text { claudication patients }\end{array}$ & 13 & 32 & RCT-PG & $\begin{array}{c}\text { EDD, } \\
\text { inflammation }\end{array}$ & $\begin{array}{l}\text { Improved EDD, } \\
\text { inflammation } \\
\text { unchanged }\end{array}$ \\
\hline $\begin{array}{l}\text { Mindrescu } \\
{[124]}\end{array}$ & 2008 & \multicolumn{2}{|c|}{$\begin{array}{l}4500 \mathrm{mg} \mathrm{n}-3 \mathrm{PUFA}+ \\
8 \begin{array}{l}\text { rosuvastatin } 10 \mathrm{~g} \\
\text { versus rosuvastatin } \\
10 \mathrm{~g}\end{array}\end{array}$} & Dyslipidemic patients & 4 & 30 & RCT-PG & EDD, EID & $\begin{array}{l}\text { Improved EDD } \\
\text { and EID }\end{array}$ \\
\hline Rizza [125] & 2009 & \multicolumn{2}{|c|}{$\begin{array}{l}1700-2000 \mathrm{mg} \mathrm{n}-3 \\
\text { PUFA versus placebo }\end{array}$} & $\begin{array}{l}\text { Offspring of type } 2 \\
\text { diabetic subjects }\end{array}$ & 12 & 50 & RCT-PC & $\begin{array}{c}\text { EDD, } \\
\text { inflammation }\end{array}$ & $\begin{array}{c}\text { Improved EDD } \\
\text { and inflammation }\end{array}$ \\
\hline Wong [99] & 2010 & \multicolumn{2}{|c|}{$\begin{array}{l}4000 \text { mg n-3 PUFA } \\
\text { versus control } \\
\text { (olive oil) }\end{array}$} & $\begin{array}{l}\text { Type } 2 \text { diabetes } \\
\text { mellitus }\end{array}$ & 12 & 97 & RCT-PG & $\begin{array}{l}\text { EDD, CRP, } \\
\text { renal } \\
\text { function }\end{array}$ & $\begin{array}{l}\text { Improved renal } \\
\text { function; no effect } \\
\text { on EDD or CRP }\end{array}$ \\
\hline
\end{tabular}


(b) Continued.

\begin{tabular}{|c|c|c|c|c|c|c|c|c|}
\hline First author & Year & Dose & Sample & $\begin{array}{l}\text { Duration } \\
(\mathrm{w})\end{array}$ & Number & $\begin{array}{l}\text { Study } \\
\text { design }\end{array}$ & $\begin{array}{l}\text { Outcome } \\
\text { measure }\end{array}$ & Results \\
\hline Stirban [100] & 2010 & $\begin{array}{l}2000 \text { mg versus } \\
\text { control (olive oil) }\end{array}$ & $\begin{array}{c}\text { Type } 2 \text { diabetes } \\
\text { mellitus }\end{array}$ & 6 & 34 & RCT-PC & $\begin{array}{l}\text { Postprandial } \\
\text { EDD }\end{array}$ & $\begin{array}{c}\text { Improved } \\
\text { postprandial EDD }\end{array}$ \\
\hline Sanders [58] & 2011 & $\begin{array}{l}450-900 \text { or } 1800 \mathrm{mg} \\
\mathrm{n}-3 \text { PUFA vresus } \\
\text { placebo (refined oil) }\end{array}$ & Healthy subjects & 51 & 310 & RCT-PC & EDD & $\begin{array}{l}\text { Unchanged EDD } \\
\text { and EID }\end{array}$ \\
\hline $\begin{array}{l}\text { Skulas-Ray } \\
{[101]}\end{array}$ & 2011 & $\begin{array}{l}850 \text { or } 3400 \mathrm{mg} \text { versus } \\
\text { placebo }\end{array}$ & $\begin{array}{c}\text { Moderate } \\
\text { hypertriglyceridemia }\end{array}$ & 8 & 26 & RTC-PC & $\begin{array}{l}\text { EDD, IL-6, } \\
\text { CRP }\end{array}$ & $\begin{array}{l}\text { No effect on EDD, } \\
\text { IL-6, or CRP }\end{array}$ \\
\hline Moertl [103] & 2011 & $\begin{array}{l}1000 \text { or } 4000 \text { mg n-3 } \\
\text { PUFA versus placebo }\end{array}$ & $\mathrm{CHF}$ & 12 & 43 & RCT-PC & $\begin{array}{l}\text { LVEF, EDD, } \\
\text { IL-6 }\end{array}$ & $\begin{array}{l}\text { Improved LVEF, } \\
\text { EDD, and IL-6 }\end{array}$ \\
\hline $\begin{array}{l}\text { Haberka } \\
{[104]}\end{array}$ & 2011 & $\begin{array}{l}1000 \mathrm{mg} \text { n-3 PUFA } \\
\text { versus control } \\
\text { (standard diet and } \\
\text { therapy) }\end{array}$ & Previous AMI & 12 & 40 & RCT-PG & EDD, EID & $\begin{array}{l}\text { Improved EDD; } \\
\text { EID unchanged }\end{array}$ \\
\hline Din [105] & 2013 & $\begin{array}{l}2000 \text { mg n-3 PUFA } \\
\text { versus placebo }\end{array}$ & Cigarette smokers & 6 & 20 & RCT-PC & $\begin{array}{c}\text { EDD, } \\
\text { P-selectin, } \\
\text { CD40L }\end{array}$ & $\begin{array}{c}\text { Improved EDD } \\
\text { and P selectin; } \\
\text { CD40L unchanged }\end{array}$ \\
\hline Din [108] & 2013 & $\begin{array}{l}2000 \text { mg n-3 PUFA } \\
\text { versus placebo }\end{array}$ & Previous AMI & 6 & 20 & RCT-PC & $\begin{array}{c}\text { EDD, } \\
\text { P-selectin, } \\
\text { CD40L }\end{array}$ & No effect \\
\hline
\end{tabular}

n-3 PUFA, omega-3 polyunsaturated fatty acids; EPA, eicosapentaenoic acid; DHA, docosahexaenoic acid; EDD, endothelium dependent dilation; EID: endothelium independent dilation; AMI: acute myocardial infarction; CHF: chronic heart failure; LVEF: left ventricular ejection fraction; IL6: interleukin-6; CRP: C reactive protein; AES, animal experimental study; RCT, randomized clinical trial; CT, clinical trial; PG, parallel groups; PC, placebo controlled; d, day; w, week.

indirectly also the triglyceride-lowering effect contributes to improved endothelial function often observed in these conditions.

\section{8. n-3 PUFA and Endothelial Dysfunction: In Vivo Human Studies}

n-3 PUFA show the potential to improve endothelial dysfunction by activating NO production via different mechanisms and by reducing vascular oxidative stress and inflammation (Figure 1). Many studies have evaluated the effect of n3 PUFA on human endothelial function and the results have been reported by two recent meta-analyses $[95,96]$, whose conclusions are not completely concordant. For review reasons, we will focus on studies published during the last 5 years. One issue that needs to be considered when evaluating the effect of n-3 PUFA supplementation on endothelial function is the poverty of data on n-3 PUFA basal enrichment in the patient population under consideration. The amount of n-3 PUFA in biological membranes can be directly extrapolated by measuring the omega-3 index in red blood cell membranes $[97,98]$ or by determining plasma concentrations of EPA + DHA which have shown a good correlation with their membrane levels [89]. This point is crucial as conditions characterized by n-3 PUFA depletion may mostly benefit from their supplementation. In a recent study conducted in an experimental model of menopause, deficiency of n-3 PUFA demonstrated by low omega-3 index was associated with endothelial dysfunction and increased oxidative stress, which were reversed by efficient n-3 PUFA supplementation, resulting in normalization of omega-3 index [82]. Having said this, clinical trials on the effects of n-3 PUFA on endothelial function are significantly heterogeneous in

(i) number of included participants;

(ii) inclusion criteria: age of participants, healthy or disease state, have been studied;

(iii) markers of endothelial function: in addition to flowmediated dilation, at least 7 different classes of surrogate markers have been tested in the last 5 years. The most frequent categories tested, according to their different pathophysiological roles, are proinflammatory and anti-inflammatory cytokines, endothelial progenitor cells, markers of platelet activation, of fibrinolysis, of thrombosis, and of coagulation, and markers of oxidative stress [98-102];

(iv) dose and duration of treatment: doses ranging from 0.45 up to 4 grams have been tested as well as treatments ranging from 4 to 52 weeks $[58,103,104]$;

(v) forms of n-3 PUFA: EPA, DHA, or ALA has been administered alone or in combination;

(vi) concomitant therapy: most of the studies on disease states do not provide accurate information on concomitant therapy, particularly on drugs known to improve endothelial function such as statins and ACE inhibitors/angiotensin receptor blockers. The presence of a robust concomitant therapy might improve endothelial function independently of n-3 PUFA (especially at low doses) in high risk patients. 
So far, most studies have cautiously suggested that supplementation with n-3 PUFA might improve endothelial function. However, whether the amplitude of this effect depends on healthy or disease state or on the administered dose or whether the n-3 PUFA composition of supplementation differentially affects the outcome is currently unclear. In smokers, where the bias of concomitant therapies is not an issue, two recent studies have shown that n-3 PUFA supplementation for six and twelve weeks, respectively, improves endothelial function $[54,105]$. In patients with moderate cardiovascular risk Seely et al. performed a meta-analysis where again quality and power of the available studies precluded any definite conclusion [106]. However, low-strength evidence seemed to suggest a benefit of n-3 PUFA in endothelial dysfunction. Similar results have been reported in high risk patients with previous myocardial infarction [104] although a recent comprehensive meta-analysis and a recent study in a similar population do not confirm these findings $[107,108]$.

When considering moderate/high risk patients assuming polytherapy, the issue of cost/benefit in terms of clinical efficiency and potential harms is important. Therefore, stronger evidence is needed before large scale prescription of n-3 PUFA in this population.

\section{Endothelial-Independent Vasodilation and n-3 PUFA}

Technically, flow-mediated dilation is the result of both endothelial-derived vasodilation (which is mainly NOdependent) and endothelial-independent vasorelaxation. The latter depends on the ability of smooth muscle cells to respond to nitric oxide and therefore measures the integrity of arterial media. The hypotensive effect of n-3 PUFA can partly be explained by this mechanism. Therefore, when measuring FMD in vivo in humans, it is difficult to dissect the relative contribution of endothelium and smooth muscle cells unless a selective agonist is administered (muscarinic receptor agonist for EDD and $\mathrm{NO}$ donor for EID). A recent study addressed the physiologic mechanisms of EPA-induced relaxation in pulmonary arteries from an animal model [109] and showed that in these conditions the contribution of endothelium-derived NO release to vasodilation is prominent, while that mediated by endothelium-independent mechanisms is negligible.

These findings are in line with data from human studies, showing that when controlled trials assessing EID are considered, no significant effect of n-3 PUFA on EID is observed [96].

\section{Conclusive Remarks}

By targeting both arterial wall stiffness and endothelial dysfunction n-3 PUFA have the potential to beneficially impact arterial wall remodeling and cardiovascular outcomes. Their pleiotropic effects on systemic inflammation, modulation of lipid profile, and platelet aggregation contribute to the reduction of cardiovascular risk. Although dissecting the specific contribution of structural arterial remodeling to overall cardiovascular risk is difficult from experimental studies conducted in high risk populations, current results are encouraging. From here comes the need for large scale trials, advocated by most of the available literature. This process is likely to involve selection of homogenous patient populations in terms of target disease, endpoints, and modality of treatment.

$\begin{array}{ll}\text { Abbreviations } \\ \text { NO: } & \text { Nitric oxide } \\ \text { eNOS: } & \text { Endothelial nitric oxide synthase } \\ \text { iNOS: } & \text { Inducible nitric oxide synthase } \\ \text { NADPH: } & \text { Nicotinamide adenine dinucleotide phosphate } \\ \text { ROS: } & \text { Reactive oxygen species } \\ \text { TNF } \alpha: & \text { Tumor necrosis factor alpha } \\ \text { IL-1 } \beta: & \text { Interleukin } 1 \text { beta } \\ \text { IL-6: } & \text { Interleukin } 6 \\ \text { COX-2: } & \text { Cyclooxygenase-2 } \\ \text { PGE }: & \text { Prostaglandin } E_{2} \\ \text { SOD: } & \text { Superoxide dismutase } \\ \text { AMPK: } & \text { AMP-activated protein kinase } \\ \text { EPA: } & \text { Eicosapentaenoic acid } \\ \text { DHA: } & \text { Docosahexaenoic acid } \\ \text { ALA: } & \text { Alpha-linolenic acid } \\ \text { ADMA: } & \text { Asymmetric dimethylarginine } \\ \text { PWV: } & \text { Pulse wave velocity } \\ \text { IMT: } & \text { Intima-media thickness } \\ \text { EDD: } & \text { Endothelial-dependent dilation } \\ \text { EID: } & \text { Endothelial-independent dilation. }\end{array}$

\section{Conflict of Interests}

The authors declare that there is no conflict of interests regarding the publishing of this paper.

\section{References}

[1] A. Avolio, “Arterial stiffness," Pulse, vol. 1, no. 1, pp. 14-28, 2013.

[2] R. Kwak, M. Bäck, M.-L. Bochaton-Piallat et al., "Biomechanical factors in atherosclerosis: mechanisms and clinical implications," European Heart Journal, vol. 35, no. 43, pp. 3013-3020, 2014.

[3] E. Gutiérrez, A. J. Flammer, L. O. Lerman, J. Elízaga, A. Lerman, and F.-A. Francisco, "Endothelial dysfunction over the course of coronary artery disease," European Heart Journal, vol. 34, no. 41, pp. 3175-3182, 2013.

[4] J. E. Deanfield, J. P. Halcox, and T. J. Rabelink, "Endothelial function and dysfunction: testing and clinical relevance," Circulation, vol. 115, no. 10, pp. 1285-1295, 2007.

[5] C. Vlachopoulos, K. Aznaouridis, and C. Stefanadis, "Prediction of cardiovascular events and all-cause mortality with arterial stiffness: a systematic review and meta-analysis," Journal of the American College of Cardiology, vol. 55, no. 13, pp. 1318$1327,2010$.

[6] P. O. Bonetti, L. O. Lerman, and A. Lerman, "Endothelial dysfunction: a marker of atherosclerotic risk," Arteriosclerosis, 
Thrombosis, and Vascular Biology, vol. 23, no. 2, pp. 168-175, 2003.

[7] D. Mozaffarian and J. H. Y. Wu, "Omega-3 fatty acids and cardiovascular disease: effects on risk factors, molecular pathways, and clinical events," Journal of the American College of Cardiology, vol. 58, no. 20, pp. 2047-2067, 2011.

[8] M. F. O'Rourke and J. Hashimoto, "Mechanical factors in arterial aging: a clinical perspective," Journal of the American College of Cardiology, vol. 50, no. 1, pp. 1-13, 2007.

[9] S. Laurent, J. Cockcroft, L. Van Bortel et al., "Expert consensus document on arterial stiffness: methodological issues and clinical applications," European Heart Journal, vol. 27, no. 21, pp. 2588-2605, 2006.

[10] S. G. Pickering, "Arteriosclerosis and atherosclerosis. The need for clear thinking," The American Journal of Medicine, vol. 34, no. 1, pp. 7-18, 1963.

[11] I. B. Wilkinson, C. M. McEniery, and J. R. Cockcroft, "Arteriosclerosis and atherosclerosis: guilty by association," Hypertension, vol. 54, no. 6, pp. 1213-1215, 2009.

[12] M. P. Pase, N. A. Grima, and J. Sarris, "The effects of dietary and nutrient interventions on arterial stiffness: a systematic review," The American Journal of Clinical Nutrition, vol. 93, no. 2, pp. 446-454, 2011.

[13] R. de Caterina and A. Zampolli, "Omega-3 fatty acids, atherogenesis, and endothelial activation," Journal of Cardiovascular Medicine, vol. 8, supplement 1, pp. S11-S14, 2007.

[14] P. Saravanan, N. C. Davidson, E. B. Schmidt, and P. C. Calder, "Cardiovascular effects of marine omega-3 fatty acids," The Lancet, vol. 376, no. 9740, pp. 540-550, 2010.

[15] W. S. Harris, M. Miller, A. P. Tighe, M. H. Davidson, and E. J. Schaefer, "Omega-3 fatty acids and coronary heart disease risk: clinical and mechanistic perspectives," Atherosclerosis, vol. 197, no. 1, pp. 12-24, 2008.

[16] H. Weintraub, "Update on marine omega-3 fatty acids: management of dyslipidemia and current omega-3 treatment options," Atherosclerosis, vol. 230, no. 2, pp. 381-389, 2013.

[17] G. K. Hansson, "Inflammation, atherosclerosis, and coronary artery disease," The New England Journal of Medicine, vol. 352, no. 16, pp. 1685-1695, 2005.

[18] C. L. Chang, T. Seo, M. Matsuzaki, T. S. Worgall, and R. J. Deckelbaum, " $n-3$ fatty acids reduce arterial LDL-cholesterol delivery and arterial lipoprotein lipase levels and lipase distribution," Arteriosclerosis, Thrombosis, and Vascular Biology, vol. 29, no. 4, pp. 555-561, 2009.

[19] C. L. Chang, C. Torrejon, U. J. Jung, K. Graf, and R. J. Deckelbaum, "Incremental replacement of saturated fats by n3 fatty acids in high-fat, high-cholesterol diets reduces elevated plasma lipid levels and arterial lipoprotein lipase, macrophages and atherosclerosis in LDLR-/-mice," Atherosclerosis, vol. 234, no. 2, pp. 401-409, 2014.

[20] A. C. Doran, N. Meller, and C. A. McNamara, "Role of smooth muscle cells in the initiation and early progression of atherosclerosis," Arteriosclerosis, Thrombosis, and Vascular Biology, vol. 28, no. 5, pp. 812-819, 2008.

[21] Q. N. Diep, R. M. Touyz, and E. L. Schiffrin, "Docosahexaenoic acid, a peroxisome proliferator-activated receptor- $\alpha$ ligand, induces apoptosis in vascular smooth muscle cells by stimulation of p38: mitogen-activated protein kinase," Hypertension, vol. 36 , no. 5, pp. 851-855, 2000.
[22] T. Shiina, T. Terano, J. Saito, Y. Tamura, and S. Yoshida, "Eicosapentaenoic acid and docosahexaenoic acid suppress the proliferation of vascular smooth muscle cells," Atherosclerosis, vol. 104, no. 1-2, pp. 95-103, 1993.

[23] M. Goua, S. Mulgrew, J. Frank, D. Rees, A. A. Sneddon, and K. W. J. Wahle, "Regulation of adhesion molecule expression in human endothelial and smooth muscle cells by omega-3 fatty acids and conjugated linoleic acids: involvement of the transcription factor NF- $\kappa$ B?" Prostaglandins Leukotrienes and Essential Fatty Acids, vol. 78, no. 1, pp. 33-43, 2008.

[24] F. Thies, J. M. C. Garry, P. Yaqoob et al., "Association of n3 polyunsaturated fatty acids with stability of atherosclerotic plaques: a randomised controlled trial," The Lancet, vol. 361, no. 9356, pp. 477-485, 2003.

[25] A. L. Cawood, R. Ding, F. L. Napper et al., "Eicosapentaenoic acid (EPA) from highly concentrated n-3 fatty acid ethyl esters is incorporated into advanced atherosclerotic plaques and higher plaque EPA is associated with decreased plaque inflammation and increased stability," Atherosclerosis, vol. 212, no. 1, pp. 252259, 2010.

[26] P. Pignoli, E. Tremoli, A. Poli et al., "Intimal plus medial thickness of the arterial wall: a direct measurement with ultrasound imaging," Circulation, vol. 74, no. 6, pp. 1399-1406, 1986.

[27] E. M. Balk, A. H. Lichtenstein, M. Chung, B. Kupelnick, P. Chew, and J. Lau, "Effects of omega-3 fatty acids on coronary restenosis, intima-media thickness, and exercise tolerance: a systematic review," Atherosclerosis, vol. 184, no. 2, pp. 237-246, 2006.

[28] T. Mita, H. Watada, T. Ogihara et al., "Eicosapentaenoic acid reduces the progression of carotid intima-media thickness in patients with type 2 diabetes," Atherosclerosis, vol. 191, no. 1, pp. 162-167, 2007.

[29] E. M. Hjerkinn, M. Abdelnoor, L. Breivik et al., "Effect of diet or very long chain $\omega$-3 fatty acids on progression of atherosclerosis, evaluated by carotid plaques, intima-media thickness and by pulse wave propagation in elderly men with hypercholesterolaemia," European Journal of Cardiovascular Prevention and Rehabilitation, vol. 13, no. 3, pp. 325-333, 2006.

[30] A. Sekikawa, T. Kadowaki, A. El-Saed et al., "Differential association of docosahexaenoic and eicosapentaenoic acids with carotid intima-media thickness," Stroke, vol. 42, no. 9, pp. 2538-2543, 2011.

[31] A. Benetos, S. Laurent, R. G. Asmar, and L. Patrick, "Large artery stiffness in hypertension," Journal of Hypertension, Supplement, vol. 15, no. 2, pp. S89-S97, 1997.

[32] J. Cabo, R. Alonso, and P. Mata, "Omega-3 fatty acids and blood pressure," British Journal of Nutrition, vol. 107, supplement 2, pp. S195-S200, 2012.

[33] P. E. Miller, M. Van Elswyk, and D. D. Alexander, "Long-chain omega-3 fatty acids eicosapentaenoic acid and docosahexaenoic acid and blood pressure: a meta-analysis of randomized controlled trials," American Journal of Hypertension, vol. 27, no. 7, pp. 885-896, 2014.

[34] A. L. Catapano, Ž. Reiner, G. de Backer et al., "ESC/EAS Guidelines for the management of dyslipidaemias. The Task Force for the management of dyslipidaemias of the European Society of Cardiology (ESC) and the European Atherosclerosis Society (EAS)," Atherosclerosis, vol. 217, supplement 1, pp. 1-44, 2011.

[35] V. Salomaa, W. Riley, J. D. Kark, C. Nardo, and A. R. Folsom, "Non-insulin-dependent diabetes mellitus and fasting glucose 
and insulin concentrations are associated with arterial stiffness indexes: the ARIC study," Circulation, vol. 91, no. 5, pp. 14321443, 1995.

[36] S. P. Whelton, R. Blankstein, M. H. Al-Mallah et al., "Association of resting heart rate with carotid and aortic arterial stiffness: multi-ethnic study of atherosclerosis," Hypertension, vol. 62, no. 3, pp. 477-484, 2013.

[37] P. L. McLennan, "Myocardial membrane fatty acids and the antiarrhythmic actions of dietary fish oil in animal models," Lipids, vol. 36, supplement, pp. S111-S114, 2001.

[38] A. Leaf, J. X. Kang, Y.-F. Xiao, and G. E. Billman, "Clinical prevention of sudden cardiac death by $n-3$ polyunsaturated fatty acids and mechanism of prevention of arrhythmias by n-3 fish oils," Circulation, vol. 107, no. 21, pp. 2646-2652, 2003.

[39] D. Mozaffarian and J. H. Y. Wu, "Omega-3 fatty acids and cardiovascular disease: effects on risk factors, molecular pathways, and clinical events," Journal of the American College of Cardiology, vol. 58, no. 20, pp. 2047-2067, 2011.

[40] A. A. Mangoni, L. Mircoli, C. Giannattasio, G. Mancia, and A. U. Ferrari, "Effect of sympathectomy on mechanical properties of common carotid and femoral arteries," Hypertension, vol. 30, no. 5, pp. 1085-1088, 1997.

[41] X. Peng, S. Haldar, S. Deshpande, K. Irani, and D. A. Kass, "Wall stiffness suppresses Akt/eNOS and cytoprotection in pulseperfused endothelium," Hypertension, vol. 41, no. 2, pp. 378-381, 2003.

[42] I. B. Wilkinson, A. Qasem, C. M. McEniery, D. J. Webb, A. P. Avolio, and J. R. Cockcroft, "Nitric oxide regulates local arterial distensibility in vivo," Circulation, vol. 105, no. 2, pp. 213-217, 2002.

[43] M. Schmitt, A. Avolio, A. Qasem et al., "Basal NO locally modulates human iliac artery function in vivo," Hypertension, vol. 46, no. 1, pp. 227-231, 2005.

[44] T. Yaginuma, A. Avolio, M. O’Rourke et al., "Effect of glyceryl trinitrate on peripheral arteries alters left ventricular hydraulic load in man," Cardiovascular Research, vol. 20, no. 2, pp. 153$160,1986$.

[45] T. A. Mori, G. F. Watts, V. Burke, E. Hilme, I. B. Puddey, and L. J. Beilin, "Differential effects of eicosapentaenoic acid and docosahexaenoic acid on vascular reactivity of the forearm microcirculation in hyperlipidemic, overweight men," Circulation, vol. 102, no. 11, pp. 1264-1269, 2000.

[46] D. Kenny, D. C. Warltier, J. A. Pleuss, R. G. Hoffmann, T. L. Goodfriend, and B. M. Egan, "Effect of omega-3 fatty acids on the vascular response to angiotensin in normotensive men," The American Journal of Cardiology, vol. 70, no. 15, pp. 1347-1352, 1992.

[47] J. P. F. Chin, A. P. Gust, P. J. Nestel, and A. M. Dart, "Marine oils dose-dependently inhibit vasoconstriction of forearm resistance vessels in humans," Hypertension, vol. 21, no. 1, pp. 22-28, 1993.

[48] M. Sato, Y. Katsuki, H. Kanehiro et al., "Effects of ethyl allcis-5,8,11,14,17-icosapentaenoate on the physical properties of arterial walls in high cholesterol diet-fed rabbits," Journal of Cardiovascular Pharmacology, vol. 22, no. 1, pp. 1-9, 1993.

[49] V. R. Masson, A. Lucas, A.-M. Gueugneau et al., "Long-chain (n3) polyunsaturated fatty acids prevent metabolic and vascular disorders in fructose-fed rats," Journal of Nutrition, vol. 138, no. 10, pp. 1915-1922, 2008.

[50] M. M. Engler, M. B. Engler, D. M. Pierson, L. B. Molteni, and A. Molteni, "Effects of docosahexaenoic acid on vascular pathology and reactivity in hypertension," Experimental Biology and Medicine, vol. 228, no. 3, pp. 299-307, 2003.

[51] P. Losurdo, A. Grillo, E. Panizon et al., "Supplementation of omega-3 polyunsaturated fatty acids prevents increase in arterial stiffness after experimental menopause," Journal of Cardiovascular Pharmacology and Therapeutics, vol. 19, no. 1, pp. 114-120, 2014.

[52] P. Losurdo, A. Grillo, E. Panizon et al., "Baroreflex sensitivity and central hemodynamics after omega-3 polyunsaturated fatty acids supplementation in an animal model of menopause," Vascular Pharmacology, 2015.

[53] M. P. Pase, N. A. Grima, and J. Sarris, "Do long-chain n-3 fatty acids reduce arterial stiffness? A meta-analysis of randomised controlled trials," The British Journal of Nutrition, vol. 106, no. 7, pp. 974-980, 2011.

[54] G. Siasos, D. Tousoulis, E. Oikonomou et al., "Effects of omega3 fatty acids on endothelial function, arterial wall properties, inflammatory and fibrinolytic status in smokers: a cross over study," International Journal of Cardiology, vol. 166, no. 2, pp. 340-346, 2013.

[55] D. Tousoulis, A. Plastiras, G. Siasos et al., "Omega-3 PUFAs improved endothelial function and arterial stiffness with a parallel antiinflammatory effect in adults with metabolic syndrome," Atherosclerosis, vol. 232, no. 1, pp. 10-16, 2014.

[56] A. T. Y. Wong, D. C. Chan, P. H. R. Barrett, L. A. Adams, and G. F. Watts, "Supplementation with n3 fatty acid ethyl esters increases large and small artery elasticity in obese adults on a weight loss diet," Journal of Nutrition, vol. 143, no. 4, pp. 437441, 2013.

[57] M. Haiden, Y. Miyasaka, Y. Kimura et al., "Effect of eicosapentaenoic acid on regional arterial stiffness: assessment by tissue Doppler imaging," World Journal of Cardiology, vol. 4, no. 8, pp. 256-259, 2012.

[58] T. A. B. Sanders, W. L. Hall, Z. Maniou, F. Lewis, P. T. Seed, and P. J. Chowienczyk, "Effect of low doses of long-chain n-3 PUFAs on endothelial function and arterial stiffness: a randomized controlled trial," The American Journal of Clinical Nutrition, vol. 94, no. 4, pp. 973-980, 2011.

[59] M. Root, S. R. Collier, K. A. Zwetsloot, K. L. West, and M. C. McGinn, "A randomized trial of fish oil omega-3 fatty acids on arterial health, inflammation, and metabolic syndrome in a young healthy population," Nutrition Journal, vol. 12, no. 1, article 40, 2013.

[60] F. Dangardt, W. Osika, Y. Chen et al., "Omega-3 fatty acid supplementation improves vascular function and reduces inflammation in obese adolescents," Atherosclerosis, vol. 212, no. 2, pp. 580-585, 2010.

[61] Y. Fukuoka, N. Nuruki, S. Amiya et al., "Effects of a fishbased diet and administration of pure eicosapentaenoic acid on brachial-ankle pulse wave velocity in patients with cardiovascular risk factors," Journal of Cardiology, vol. 63, no. 3, pp. 211-217, 2014.

[62] H. Tomiyama, C. Matsumoto, M. Odaira et al., "Relationships among the serum omega fatty acid levels, serum C-reactive protein levels and arterial stiffness/wave reflection in Japanese men," Atherosclerosis, vol. 217, no. 2, pp. 433-436, 2011.

[63] A. Sekikawa, C. Shin, K. H. Masaki et al., "Association of total marine fatty acids, eicosapentaenoic and docosahexaenoic acids, with aortic stiffness in Koreans, whites, and Japanese Americans," American Journal of Hypertension, vol. 26, no. 11, pp. 1321-1327, 2013. 
[64] D. Tousoulis, A.-M. Kampoli, C. T. N. Papageorgiou, and C. Stefanadis, "The role of nitric oxide on endothelial function," Current Vascular Pharmacology, vol. 10, no. 1, pp. 4-18, 2012.

[65] S. Karbach, P. Wenzel, A. Waisman, T. Munzel, and A. Daiber, "eNOS uncoupling in cardiovascular diseases-the role of oxidative stress and inflammation," Current Pharmaceutical Design, vol. 20, no. 22, pp. 3579-3594, 2014.

[66] U. Förstermann and T. Münzel, "Endothelial nitric oxide synthase in vascular disease: from marvel to menace," Circulation, vol. 113, no. 13, pp. 1708-1714, 2006.

[67] E. Schulz, T. Jansen, P. Wenzel, A. Daiber, and T. Münzel, "Nitric oxide, tetrahydrobiopterin, oxidative stress, and endothelial dysfunction in hypertension," Antioxidants \& Redox Signaling, vol. 10, no. 6, pp. 1115-1126, 2008.

[68] H. Zhang, Y. Park, J. Wu et al., "Role of TNF- $\alpha$ in vascular dysfunction," Clinical Science, vol. 116, no. 3, pp. 219-230, 2009.

[69] J. A. Vita, "Endothelial function," Circulation, vol. 124, no. 25, pp. e906-e912, 2011.

[70] T. Strisciuglio, S. de Luca, E. Capuano et al., "Endothelial dysfunction: its clinical value and methods of assessment," Current Atherosclerosis Reports, vol. 16, no. 6, article 417, 2014.

[71] G. Brevetti, A. Silvestro, V. Schiano, and M. Chiariello, "Endothelial dysfunction and cardiovascular risk prediction in peripheral arterial disease: additive value of flow-mediated dilation to ankle-brachial pressure index," Circulation, vol. 108, no. 17, pp. 2093-2098, 2003.

[72] J. Yeboah, A. R. Folsom, G. L. Burke et al., "Predictive value of brachial flow-mediated dilation for incident cardiovascular events in a population-based study: the multi-ethnic study of atherosclerosis," Circulation, vol. 120, no. 6, pp. 502-509, 2009.

[73] Y. Inaba, J. A. Chen, and S. R. Bergmann, "Prediction of future cardiovascular outcomes by flow-mediated vasodilatation of brachial artery: a meta-analysis," International Journal of Cardiovascular Imaging, vol. 26, no. 6, pp. 631-640, 2010.

[74] J. J. L. Williams and T. M. Palmer, "Cavin-1: caveolae-dependent signalling and cardiovascular disease," Biochemical Society Transactions, vol. 42, no. 2, pp. 284-288, 2014.

[75] J. Layne, Z. Majkova, E. J. Smart, M. Toborek, and B. Hennig, "Caveolae: a regulatory platform for nutritional modulation of inflammatory diseases," Journal of Nutritional Biochemistry, vol. 22, no. 9, pp. 807-811, 2011.

[76] J. Ramadoss, M. B. Pastore, and R. R. Magness, "Endothelial caveolar subcellular domain regulation of endothelial nitric oxide synthase," Clinical and Experimental Pharmacology and Physiology, vol. 40, no. 11, pp. 753-764, 2013.

[77] O. Feron, C. Dessy, S. Moniotte, J.-P. Desager, and J.-L. Balligand, "Hypercholesterolemia decreases nitric oxide production by promoting the interaction of caveolin and endothelial nitric oxide synthase," The Journal of Clinical Investigation, vol. 103, no. 6, pp. 897-905, 1999.

[78] Y. Wu, C. Zhang, Y. Dong et al., "Activation of the AMPactivated protein kinase by eicosapentaenoic acid (EPA, 20:5 n3) improves endothelial function in vivo," PLoS ONE, vol. 7, no. 4, Article ID e35508, 2012.

[79] M. Omura, S. Kobayashi, Y. Mizukami et al., "Eicosapentaenoic acid (EPA) induces $\mathrm{Ca}^{2+}$-independent activation and translocation of endothelial nitric oxide synthase and endotheliumdependent vasorelaxation," FEBS Letters, vol. 487, no. 3, pp. 361366, 2001.

[80] C. L. Stebbins, J. P. Stice, C. M. Hart, F. N. Mbai, and A. A. Knowlton, "Effects of dietary decosahexaenoic acid (DHA) on
eNOS in human coronary artery endothelial cells," Journal of Cardiovascular Pharmacology and Therapeutics, vol. 13, no. 4, pp. 261-268, 2008.

[81] L. Raimondi, M. Lodovici, F. Visioli et al., "n-3 polyunsaturated fatty acids supplementation decreases asymmetric dimethyl arginine and arachidonate accumulation in aging spontaneously hypertensive rats," European Journal of Nutrition, vol. 44, no. 6, pp. 327-333, 2005.

[82] G. Gortan Cappellari, P. Losurdo, S. Mazzucco et al., "Treatment with $n-3$ polyunsaturated fatty acids reverses endothelial dysfunction and oxidative stress in experimental menopause," Journal of Nutritional Biochemistry, vol. 24, no. 1, pp. 371-379, 2013.

[83] W. Zhang, F. Fu, R. Tie et al., "Alpha-linolenic acid intake prevents endothelial dysfunction in high-fat diet-fed streptozotocin rats and underlying mechanisms," Vasa, vol. 42, no. 6, pp. 421-428, 2013.

[84] M. D. Nyby, K. Matsumoto, K. Yamamoto et al., "Dietary fish oil prevents vascular dysfunction and oxidative stress in hyperinsulinemic rats," American Journal of Hypertension, vol. 18, no. 2, pp. 213-219, 2005.

[85] D. López, X. Orta, K. Casós et al., "Upregulation of endothelial nitric oxide synthase in rat aorta after ingestion of fish oil-rich diet," American Journal of Physiology-Heart and Circulatory Physiology, vol. 287, no. 2, pp. H567-H572, 2004.

[86] D. López, C. Caballero, J. Sánchez, P. Puig-Parellada, and M. T. Mitjavila, "Free radical production in aortic rings from rats fed a fish oil-rich diet," The American Journal of Physiology-Heart and Circulatory Physiology, vol. 280, no. 6, pp. H2929-H2935, 2001.

[87] K. Casós, M. C. Zaragozá, N. Zarkovic et al., "A fish oil-rich diet reduces vascular oxidative stress in apo $\mathrm{E}^{-/}$mice," Free Radical Research, vol. 44, no. 7, pp. 821-829, 2010.

[88] T. Matsumoto, N. Nakayama, K. Ishida, T. Kobayashi, and K. Kamata, "Eicosapentaenoic acid improves imbalance between vasodilator and vasoconstrictor actions of endotheliumderived factors in mesenteric arteries from rats at chronic stage of type 2 diabetes," Journal of Pharmacology and Experimental Therapeutics, vol. 329, no. 1, pp. 324-334, 2009.

[89] S. Serini, E. Fasano, E. Piccioni, A. R. M. Cittadini, and G. Calviello, "Dietary n-3 polyunsaturated fatty acids and the paradox of their health benefits and potential harmful effects," Chemical Research in Toxicology, vol. 24, no. 12, pp. 2093-2105, 2011.

[90] T.-M. Wang, C.-J. Chen, T.-S. Lee et al., "Docosahexaenoic acid attenuates VCAM-1 expression and NF- $\kappa$ B activation in TNF$\alpha$-treated human aortic endothelial cells," Journal of Nutritional Biochemistry, vol. 22, no. 2, pp. 187-194, 2011.

[91] J. Shen, S. Shen, U. N. Das, and G. Xu, "Effect of essential fatty acids on glucose-induced cytotoxicity to retinal vascular endothelial cells," Lipids in Health and Disease, vol. 11, article 90, 2012.

[92] L. Lluís, N. Taltavull, M. Muñoz-Cortés et al., "Protective effect of the omega-3 polyunsaturated fatty acids: eicosapentaenoic acid/Docosahexaenoic acid 1:1 ratio on cardiovascular disease risk markers in rats," Lipids in Health and Disease, vol. 12, article 140, 2013.

[93] J. H. Y. Wu, L. E. Cahill, and D. Mozaffarian, "Effect of fish oil on circulating adiponectin: a systematic review and metaanalysis of randomized controlled trials," Journal of Clinical Endocrinology and Metabolism, vol. 98, no. 6, pp. 2451-2459, 2013. 
[94] E. A. Miles, T. Banerjee, and P. C. Calder, "The influence of different combinations of $\gamma$-linolenic, stearidonic and eicosapentaenoic acids on the fatty acid composition of blood lipids and mononuclear cells in human volunteers," Prostaglandins, Leukotrienes \& Essential Fatty Acids, vol. 70, no. 6, pp. 529-538, 2004.

[95] W. Xin, W. Wei, and X. Li, "Effect of fish oil supplementation on fasting vascular endothelial function in humans: a metaanalysis of randomized controlled trials," PLOS ONE, vol. 7, no. 9, Article ID e46028, 2012.

[96] Q. Wang, X. Liang, L. Wang et al., "Effect of omega-3 fatty acids supplementation on endothelial function: a meta-analysis of randomized controlled trials," Atherosclerosis, vol. 221, no. 2, pp. 536-543, 2012.

[97] W. S. Harris and C. von Schacky, "The Omega-3 Index: a new risk factor for death from coronary heart disease?" Preventive Medicine, vol. 39, no. 1, pp. 212-220, 2004.

[98] M. R. Flock, A. C. Skulas-Ray, W. S. Harris, T. D. Etherton, J. A. Fleming, and P. M. Kris-Etherton, "Determinants of erythrocyte omega-3 fatty acid content in response to fish oil supplementation: a dose-response randomized controlled trial," The Journal of the American Heart Association, vol. 2, no. 6, Article ID e000513, 2013.

[99] C.-Y. Wong, K.-H. Yiu, S.-W. Li et al., "Fish-oil supplement has neutral effects on vascular and metabolic function but improves renal function in patients with Type 2 diabetes mellitus," Diabetic Medicine, vol. 27, no. 1, pp. 54-60, 2010.

[100] A. Stirban, S. Nandrean, C. Götting et al., "Effects of n-3 fatty acids on macro- and microvascular function in subjects with type 2 diabetes mellitus," The American Journal of Clinical Nutrition, vol. 91, no. 3, pp. 808-813, 2010.

[101] A. C. Skulas-Ray, P. M. Kris-Etherton, W. S. Harris, J. P. Vanden Heuvel, P. R. Wagner, and S. G. West, "Dose-response effects of omega-3 fatty acids on triglycerides, inflammation, and endothelial function in healthy persons with moderate hypertriglyceridemia," American Journal of Clinical Nutrition, vol. 93, no. 2, pp. 243-252, 2011.

[102] K. Kawauchi, S. Tani, K. Nagao, and A. Hirayama, "Association of n-3 polyunsaturated fatty acids with soluble thrombomodulin as a marker of endothelial damage: a cross-sectional pilot study," Journal of Cardiology, vol. 64, no. 4, pp. 312-317, 2014.

[103] D. Moertl, A. Hammer, S. Steiner, R. Hutuleac, K. Vonbank, and R. Berger, "Dose-dependent effects of omega-3polyunsaturated fatty acids on systolic left ventricular function, endothelial function, and markers of inflammation in chronic heart failure of nonischemic origin: a double-blind, placebocontrolled, 3-arm study," American Heart Journal, vol. 161, no. 5, pp. 915.e1-915.e9, 2011.

[104] M. Haberka, K. Mizia-Stec, M. Mizia et al., "N-3 polyunsaturated fatty acids early supplementation improves ultrasound indices of endothelial function, but not through NO inhibitors in patients with acute myocardial infarction. N-3 PUFA supplementation in acute myocardial infarction," Clinical Nutrition, vol. 30, no. 1, pp. 79-85, 2011

[105] J. N. Din, R. M. Archer, S. A. Harding et al., "Effect of $\omega-3$ fatty acid supplementation on endothelial function, endogenous fibrinolysis and platelet activation in male cigarette smokers," Heart, vol. 99, no. 3, pp. 168-174, 2013.

[106] D. Seely, S. Kanji, F. Yazdi et al., Dietary Supplements in Adults Taking Cardiovascular Drugs, US Agency for Healthcare Research and Quality, Rockville, Md, USA, 2012.
[107] E. C. Rizos, E. E. Ntzani, E. Bika, M. S. Kostapanos, and M. S. Elisaf, "Association between omega-3 fatty acid supplementation and risk of major cardiovascular disease events: a systematic review and meta-analysis," The Journal of the American Medical Association, vol. 308, no. 10, pp. 1024-1033, 2012.

[108] J. N. Din, J. Sarma, S. A. Harding, K. Lyall, D. E. Newby, and A. D. Flapan, "Effect of $\omega-3$ fatty acid supplementation on endothelial function, endogenous fibrinolysis and platelet activation in patients with a previous myocardial infarction: a randomised controlled trial," BMJ Open, vol. 3, no. 9, Article ID e003054, 2013.

[109] T. U. Singh, K. Kathirvel, S. Choudhury, S. K. Garg, and S. K. Mishra, "Eicosapentaenoic acid-induced endotheliumdependent and -independent relaxation of sheep pulmonary artery," European Journal of Pharmacology, vol. 636, no. 1-3, pp. 108-113, 2010.

[110] G. E. McVeigh, G. M. Brennan, J. N. Cohn, S. M. Finkelstein, R. J. Hayes, and G. D. Johnston, "Fish oil improves arterial compliance in non-insulin-dependent diabetes mellitus," Arteriosclerosis, Thrombosis, and Vascular Biology, vol. 14, no. 9, pp. 1425-1429, 1994.

[111] P. Nestel, H. Shige, S. Pomeroy, M. Cehun, M. Abbey, and D. Raederstorff, "The n-3 fatty acids eicosapentaenoic acid and docosahexaenoic acid increase systemic arterial compliance in humans," American Journal of Clinical Nutrition, vol. 76, no. 2, pp. 326-330, 2002.

[112] A. M. Hill, J. D. Buckley, K. J. Murphy, and P. R. C. Howe, "Combining fish-oil supplements with regular aerobic exercise improves body composition and cardiovascular disease risk factors," The American Journal of Clinical Nutrition, vol. 85, no. 5, pp. 1267-1274, 2007.

[113] S. Wang, A. Q. Ma, S. W. Song, Q. H. Quan, X. F. Zhao, and X. H. Zheng, "Fish oil supplementation improves large arterial elasticity in overweight hypertensive patients," European Journal of Clinical Nutrition, vol. 62, no. 12, pp. 1426-1431, 2008.

[114] N. Satoh, A. Shimatsu, K. Kotani et al., "Highly purified eicosapentaenoic acid reduces cardio-ankle vascular index in association with decreased serum amyloid A-LDL in metabolic syndrome," Hypertension Research, vol. 32, no. 11, pp. 1004-1008, 2009.

[115] J. G. Ayer, J. A. Harmer, W. Xuan et al., "Dietary supplementation with n-3 polyunsaturated fatty acids in early childhood: effects on blood pressure and arterial structure and function at age 8 y, American Journal of Clinical Nutrition, vol. 90, no. 2, pp. 438-446, 2009.

[116] N. J. Sjoberg, C. M. Milte, J. D. Buckley, P. R. C. Howe, A. M. Coates, and D. A. Saint, "Dose-dependent increases in heart rate variability and arterial compliance in overweight and obese adults with DHA-rich fish oil supplementation," British Journal of Nutrition, vol. 103, no. 2, pp. 243-248, 2010.

[117] R. J. Woodman, T. A. Mori, V. Burke et al., "Effects of purified eicosapentaenoic acid and docosahexaenoic acid on platelet, fibrinolytic and vascular function in hypertensive type 2 diabetic patients," Atherosclerosis, vol. 166, no. 1, pp. 85-93, 2003.

[118] M. M. Engler, M. B. Engler, M. Malloy et al., "Docosahexaenoic acid restores endothelial function in children with hyperlipidemia: results from the early study," International Journal of Clinical Pharmacology and Therapeutics, vol. 42, no. 12, pp. 672679, 2004. 
[119] E. Ros, I. Núñez, A. Pérez-Heras et al., “A walnut diet improves endothelial function in hypercholesterolemic subjects: a randomized crossover trial," Circulation, vol. 109, no. 13, pp. 16091614, 2004.

[120] J. B. Keogh, J. A. Grieger, M. Noakes, and P. M. Clifton, "Flowmediated dilatation is impaired by a high-saturated fat diet but not by a high-carbohydrate diet," Arteriosclerosis, Thrombosis, and Vascular Biology, vol. 25, no. 6, pp. 1274-1279, 2005.

[121] A. Prabodh Shah, A. M. Ichiuji, J. K. Han et al., "Cardiovascular and endothelial effects of fish oil supplementation in healthy volunteers," Journal of Cardiovascular Pharmacology and Therapeutics, vol. 12, no. 3, pp. 213-219, 2007.

[122] S. Wright, F. M. O’Prey, M. T. McHenry et al., "A randomised interventional trial of omega-3-polyunsaturated fatty acids on endothelial function and disease activity in systemic lupus erythematosus," Annals of the Rheumatic Diseases, vol. 67, no. 6, pp. 841-848, 2008.

[123] V. Schiano, E. Laurenzano, G. Brevetti et al., "Omega-3 polyunsaturated fatty acid in peripheral arterial disease: effect on lipid pattern, disease severity, inflammation profile, and endothelial function," Clinical Nutrition, vol. 27, no. 2, pp. 241-247, 2008.

[124] C. Mindrescu, R. P. Gupta, E. V. Hermance et al., "Omega3 fatty acids plus rosuvastatin improves endothelial function in South Asians with dyslipidemia," Vascular Health and Risk Management, vol. 4, no. 6, pp. 1439-1447, 2008.

[125] S. Rizza, M. Tesauro, C. Cardillo et al., "Fish oil supplementation improves endothelial function in normoglycemic offspring of patients with type 2 diabetes," Atherosclerosis, vol. 206, no. 2, pp. 569-574, 2009. 

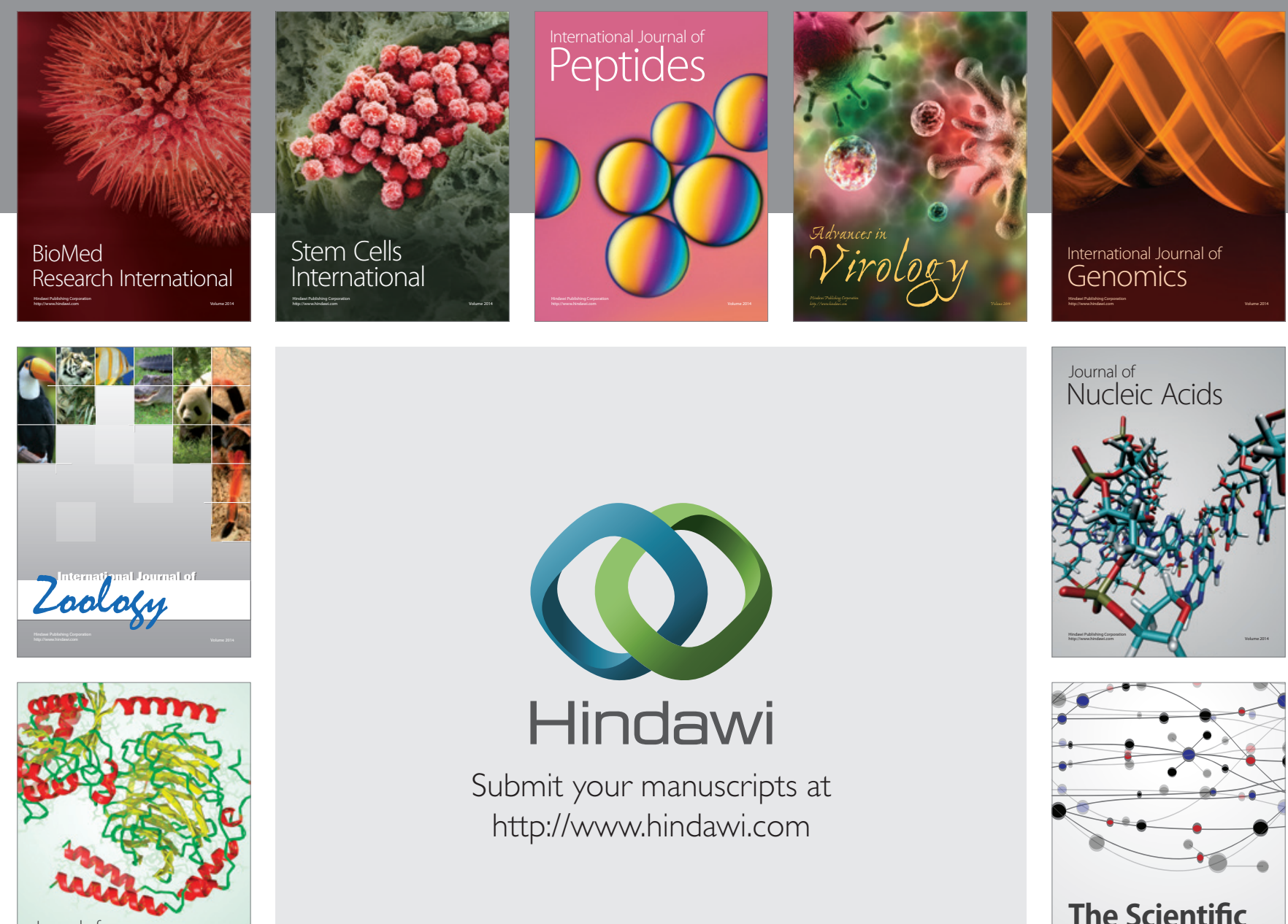

Submit your manuscripts at

http://www.hindawi.com

Journal of
Signal Transduction
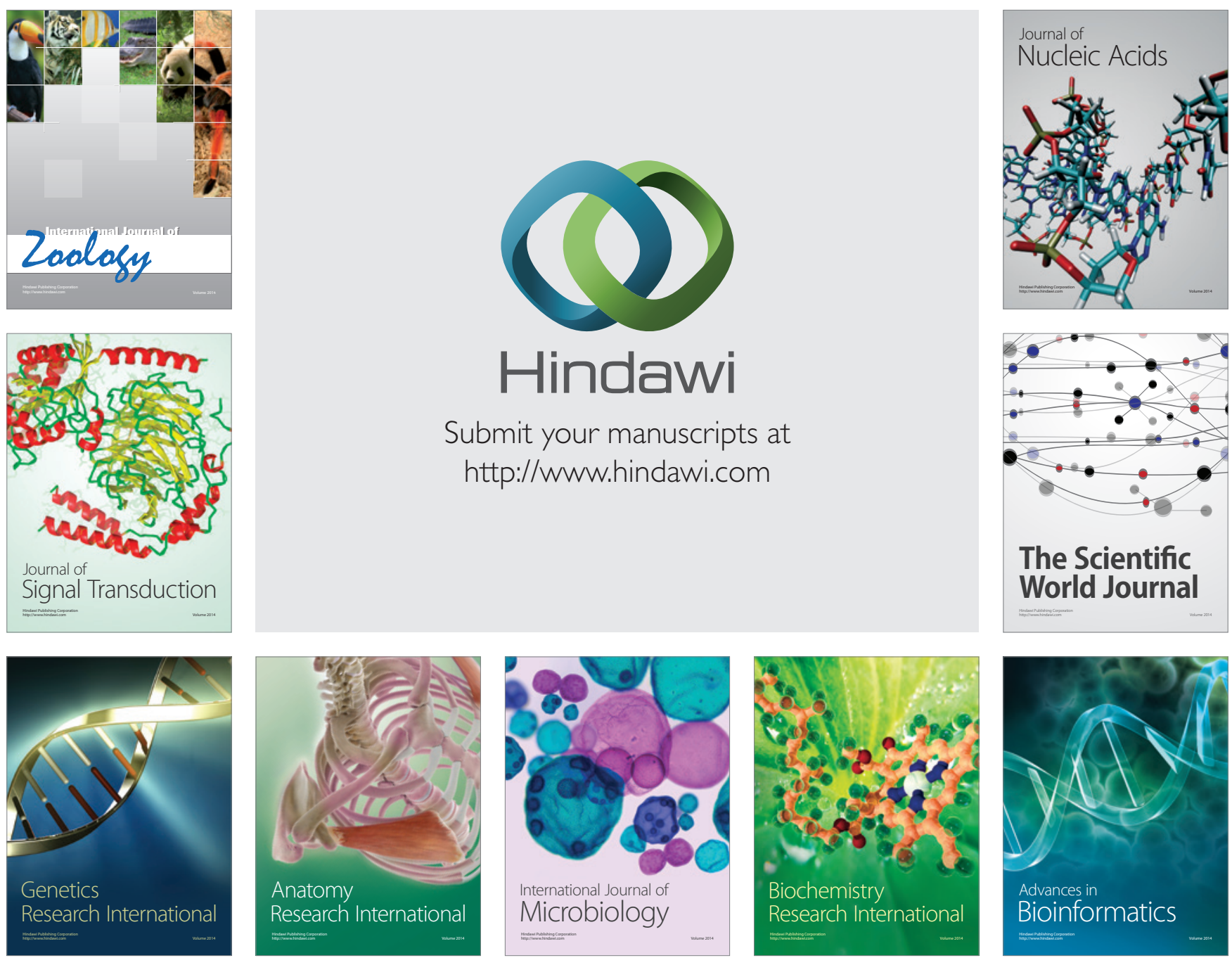

The Scientific World Journal
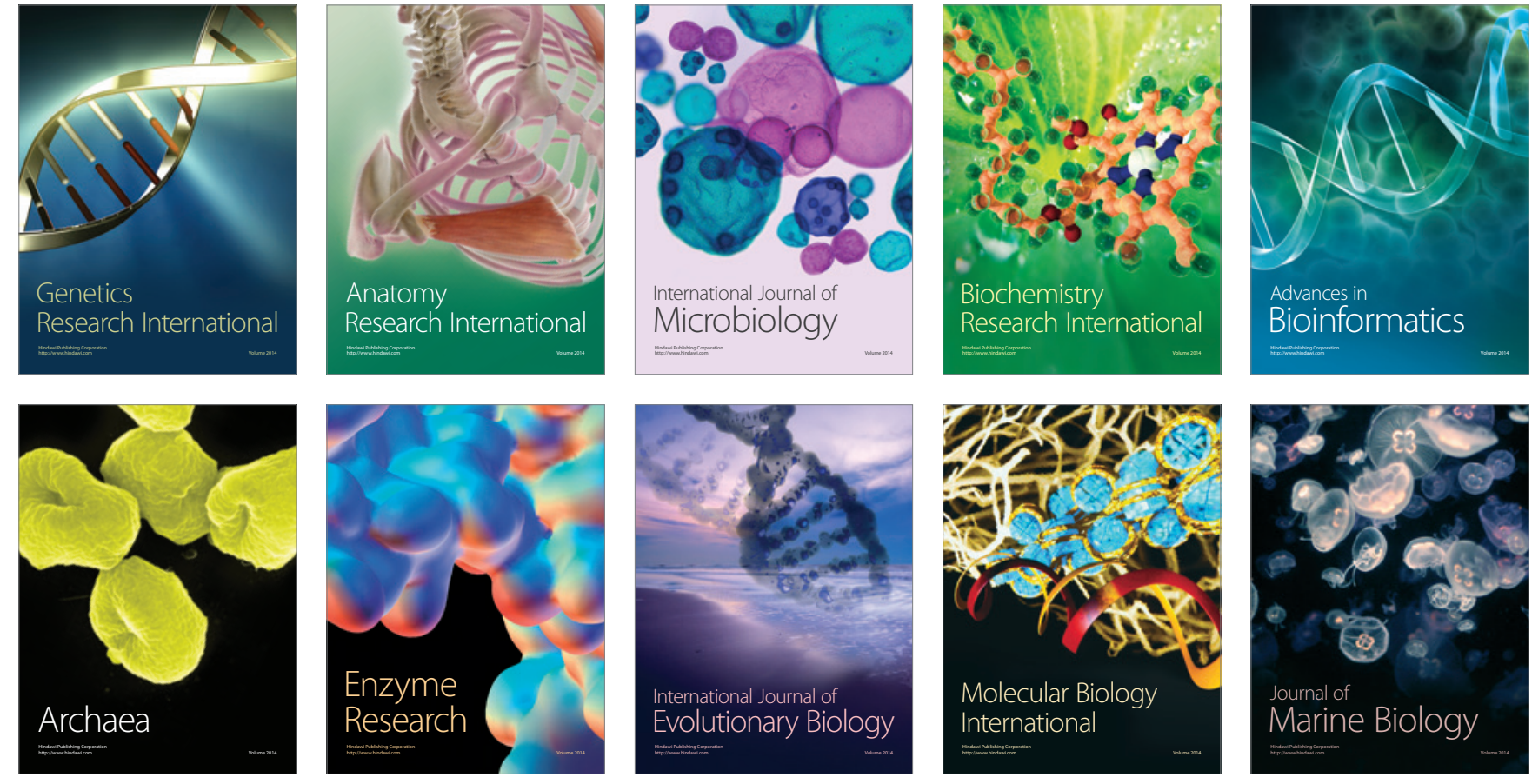